\title{
Digital Learning Resource Construction Strategy Research in "Internet+" Era
}

\author{
Fang Lu \\ The Centre of Education Technology \\ South China University of Technology \\ Guangzhou Guangdong, China \\ flu@scut.edu.cn
}

\begin{abstract}
Digital learning resource serves as an important pillar for digital learning and the formation of a learningoriented society. Domestic universities have kept to contemporary application hot-spots since the end of 1990s to construct digital learning resource and promote modern education. This paper has drawn on author's 20-year resource construction experience and put forward an "Internet + Course" digital learning resource construction strategy, which is expected to focus on learners, enhance user experience and widen multipurpose application in the form of micro-resource, to promote educational renovation as well as educational reform in order to provide better social services via open resource sharing.
\end{abstract}

Keywords-Internet+; Digital Learning Resource; User experience

\section{INTRODUCTION}

Digital learning resource is a kind of digitally processed learning resource operated on computers, internet and smart terminal to provide self-study and shareable learning resources for learners [1]. In 2015, Prime Minister Li Keqiang talked about "Internet+" action program for the first time in government work report, bringing vast reaction on innovation which cause by the integration between new technology such as mobile internet, cloud computing, big data, IOT, etc. and the various walks of life. "Internet + Education" later in the period of 13th five-year plan became a must for educational informationization to enter an upper stage of intergration innovation development. The Ten-Year Development Plan (2011-2020) for Educational informationization has made a clear announcement that a digital learning environment within enough shareable education resource for each person should be completed by 2020 [2]. In the audit and evaluation policy issued by the Ministry of Education on undergraduate teaching in ordinary universities, "Conditions and Resource Construction in Educational informationization" is considered to be the key auditing point in educational resource program and educational construction element, which shows learning resource is the basis of educational informationization. Therefore, it is an important domestic strategy on educational development to take advantage of information technology to improve construction and application of quality educational resources and to drive modern education through educational informationization [3]. During the time of "Internet+", how to use current learning resource under web thinking and technical optimization and make "Internet + Learning Resource" better served in teaching and learning has become one of the most important emphases in "Internet + Education" research.

\section{THE HISTORY OF DIGITAL LEARNING RESOURCE CONSTRUCTION}

The construction of digital learning resource in China started at the end of $1990 \mathrm{~s}$. Projected by the Ministry of Education, it focused on the contemporary new theory, new technology and new application point and developed the construction of digital learning resource and its application project which mostly includes the key national scientific and technological project of development and application project on CALL software in the Ninth Five-Year Plan in 1996 (project 96-750), new-century online courses in 2000, quality courses in 2003, quality open video courses and quality sharing courses in 2012, MOOC (Massive Open Online Course) in 2013 , etc. Under the lead of these projects, each provincial ministry of education started corresponding construction programs and each university also started the digital learning resource construction programs.

Such construction can make digital learning resource the essential teaching resource in universities, with abundant, multi-level and open forms. The carrier of the resource expands from computers, tablet computers to cellphones and the way to present it varies from class teaching, self-study, and offline study, fragmented study to other forms to develop resource modules suitable for different ways of teaching and learning and improve the training quality of innovative talents in information time. In the aspect of course development, digital learning resource can accelerate teachers and students' potential knowledge and make it explicit knowledge for courses, which helps to lead the course construction in each university. In the aspect of professional development of teachers, digital learning resource can strengthen their technology applied ability to improve the class teaching and to change learning methods of students. Meanwhile, it also enriches teachers' technological pedagogical content knowledge (TPCK) and promotes their professional development. Therefore, digital learning teaching resource plays a significant role in pushing domestic higher education development, and educational innovation and deepening the educational reform. 
With the approaching of mobile Internet and the time of "Internet+" , learning resource including MOOC brings about learning reform for students. The after $00 \mathrm{~s}$, digital natives, require diverse resource forms. Thus, it is necessary to focus on learners and "Internet + Course" and to consider university teaching resource construction through Internet thinking to build teaching resource.

\section{THE FEATURE OF DIGITAL LEARNING RESOURCE UNDER WEB THINKING}

The core point in web thinking is "open, equal, interactive and cooperative", the users' way of thinking, which pursues the excellent user experience, the cross-border integration and innovation [4]. Based on such thoughts, digital learning resource has features as followings:

\section{A. Diversified Application}

New learning methods that are relied on digital learning resource such as online learning, mobile learning, blended learning, ubiquitous learning and micro-learning have become a new favorite for learners [5].

\section{B. User-oriented}

The resource construction should be derived from learners' demand and be user-oriented. The orientation on content rather than technology brings better user experience.

\section{Open and Share}

To open and share is the original impetus for internet development [6]. During the process, collective wisdom and continuous optimization can be collected to broaden the influence of digital learning resource.

\section{Fragmentation}

Mobile internet leads the new trend in internet development. Smartphones, tablet computers, e-book readers, appliances like refrigerators, and wearable stuff including glasses have become the popular wifi-terminal. Micro-resource can better satisfy learners' demand to do ubiquitous learning and fragmented learning by taking advantage of ubiquitous terminals.

\section{IV.CONSTRUCTION STRATEGY ON DIGITAL LEARNING RESOURCE IN “INTERNET" ERA}

\section{A. Application of Demand Oriented and Top-level Strategy}

Teaching resource construction is instructed by the principles of supply-side structural reform, followed by the high quality supply, learners' demand and clear goals of resource construction. It helps to develop digital learning resource construction, improve user experience and increase user stickiness.

Take class teaching for example, in the research on university students in May 2017, 35.65\% students find teaching PPT with normal quality. 50.47\% think teachers are always reading their PPTs. $33.75 \%$ consider there is little interaction between teachers and students. $10.41 \%$ students think teachers are not skillful in using body languages and $14.2 \%$ think teachers are unfamiliar with operation of class equipment. Therefore, generally speaking, class teaching resource in universities should focus on improving class teaching PPTs and interaction.

Take another example of MOOC, universities are suggested to have an integrated plan on the school-base MOOC within policies. Quality and content rather than quantities should be taken into account to meet the requirement of the development of university. Such as the professional instruction online courses in University of Ningbo, students are handed over the right to choose their major. The online courses targeting the freshmen offer professional instruction courses on minor major to increase academic cognition and interest for students and help them to choose suitable and satisfactory course according to their personal conditions and interest, which meanwhile benefits the recruitment and promotion in the university. University of Wuhan also opens a compulsory course named Ethical and Professional Standards for Postgraduate Students to foster good academic and standardized manners in postgraduate grades.

Except for application, we can also actively invite teachers inside and outside the universities, overseas scholars, young teachers (especially those with overseas study background) inside the university to film MOOC, teaching videos or microvideos. Furthermore, it is more important to do effective promotion and application work, increase courses audiences and avoid the record-save-record closed ring.

\section{B. Project Set-up Strategy Applied in Incentive Measures}

Mainly lead by resource construction and innovative application, the strategy pays attention to reinforcing the setup of educational technology research project and achieving concurrent construction of resource and application while tilting forward young teachers.

According to survey data of newly recruited teachers' prejob training in recent five years, those teachers have high motivation on development and design of multi-media teaching resource. However, the motivation of those who are skillful in information technology is suppressed by lack of relative study on educational technology research and application toward young teachers in universities, as well as by great stress and inadequate incentive measures. Therefore, universities should conduct more study on information technology research and application or set up special study of information technology research and application in teaching research project in universities. Those set up projects will be held annually and in the mechanism encourage young teachers who have never got the support from such project.

Under the close combination of present information teaching hotspot with its internal connection, those set-up projects are held with concurrent set-up of resource and application and require resource to serve for the application. Based on such principle, universities open following digital learning resource construction projects. The level and input of the project is not supposed to be lower than that in universitylevel teaching reform research project. Take the projects with 32 credits for example, its specific classification and requirement are listed below: 
1) Application project in micro-course and flipped class

The project requires for over ten micro videos, microvideo-based flipped class teaching experiments for at least two semesters, a teaching reform with no less than 8 credits in each semester, five micro-video-based flipped class teaching cases and teaching demonstration classes with no less than 2 credits.

\section{2) Mobile teaching application project based on cellphones}

The project requires for an at least 3-unit cellphone based reform in flipped class teaching or class teaching interaction and the like.

\section{3) Interactive teaching project in information technology} support classes

The project requires to take advantage of free class information feedback system such as Yu course, UMU, Netban to promote interactive teaching in classes.

\section{4) Blended learning project based on MOOC or SPOC}

Information teaching has become the important teaching form across the country. Those open teaching resource lead by MOOC in particular becomes a reforming wave in universities. Many universities, especially nationally and internationally famous ones all start their MOOC resource construction and produce many quality resources. Apart from self-built MOOC, it is also necessary to take in outside quality MOOC resource and explore blended learning based on open online teaching resource.

The project requires to make use of present MOOC or oncampus SPOC platform to build blended teaching combined with on-line and off-line face-to-face learning. During the project, online open teaching resource is applied in the practical teaching in order to achieve combined class teaching with online open courses and traditional on-campus face-toface teaching and moreover deepen the educational reform, create new educational models and improve teaching quality.

5) micro-teaching and reviewing project for young teachers

With the help of auto-recording classrooms, young teachers are required to make complete class teaching videos and invite one to two teachers including supervisors, office and school administrators and people at the same level to choose videos with at least $1 / 3$ credits to do teaching analysis and review in order to make progress the next time.

\section{Design and development process applies crowdsourcing strategy}

The crowdsourcing form on the basis of multi-level convergence introduces undergraduate, postgraduate students and companies to collect their wisdom and do cooperative construction. The process is promoted to refer to the form of cooperative open resource, which is a kind of teaching, learning and researching resource provided under the intellectual property arrangements in public and with permission of free application and modification [7]. Under the form of crowdsourcing and corporation, it is also suggested to digitally transform courses and majors, optimize resource supply and service models, informationize teaching and learning method, push the transformation of research result to quality educational teaching resource and improve the quality and open level of teaching resource.

Meanwhile, traditional border between knowledge producers and consumers is gradually vanishing with learners transforming from knowledge consumers to convergent groups with knowledge producers, the prosumers [8-9]. Students are creating resource while consuming it.

Therefore, resource form is gradually growing diverse. Generative course resource is referred to the type of resource created during the teaching process, the best illustration of teaching process and actual learning situation. It also has the feature of being procedural, participative and evolutionary [10]. With the aid of online teaching platform, this type of resource accumulates teaching and learning activities and data. Highlevel teaching support platform which can be used to unify the course resource has significant influence on students' learning and evaluation, teaching, research on teaching, teaching documents and so on. For example, teachers are able to prepare for a certain teaching content through various terminals, and finally create controls including typography and all kinds of teaching interaction (like check-in, Q\&A, tests, voting, competitive respond, people selection, documents, etc.), various forms of exercises, examination databases and teaching plans; classes can host temporary activities; documentation resource is pushed before classes; documents are discussed in classes; question databases; things like class handwriting scripts and teacher's teaching process can be saved in the form of micro-video, video, teaching plan, document and the like in order to be reused after class.

\section{Use of micro-resource and mobile strategy in application}

Under the existing concept of fragmented learning, MOOC, ubiquitous learning, mobile era and "micro" era, micro resource has become the most critical form for information teaching resource. The knowledge spreading system and channels for teachers, magazines, press and students have been flattened. Teaching contents, research and work experience and results and so on will be published in the micro resource form like micro video and blog on the MOOC and media platforms to support fragmented learning and ubiquitous learning via rapid spread.

The support on mobile media and micro resource management platform and metadata description helps to build systematic micro resource. Making use of Semantic Web and ontology based metadata description method can make it flexible and accurate to demonstrate the resource character and convenient for learners to do resource searching and classification. It also increases the recall ratio and accuracy in the searching and becomes easily discovered and collected by data mining tools in order to complete intelligent resource searching and pushing, realize flexible sharing, connection and reuse of distributed resource in ubiquitous learning environment and furthermore improve the adaptability in learning system and exclusive service ability for targeting users.

\section{E. Use of Social Function Expansion Strategy in Service}

Learning resource is a key factor in the whole e-learning ecosystem. Except for being a knowledge carrier and knowledge provider for users, it as well serves in social 
cognitive network as the "web bridge", in other word, a resource-tied learning community composed of users with similar or same learning interest and demand [11]. As a result, whether e-learning community can be easily constructed deserves full consideration during the design and production process of digital learning resource, like MOOC and other digital resource which accumulates interpersonal relationship in the learning process and build individual learning network for their own.

Another function of being socialization is implemented as a service function in universities through opening and sharing on quality digital resource, promotion of equal education and construction of learning society.

\section{CONCLUSION}

China's Medium- and Long-Term Talent Development Plan (2010-2020) has stated that the learning society will be completed by 2020. Digital learning resource serves as an important pillar for digital learning and the formation of a learning-oriented society. It needs to follow the web thinking, focus on learners, start from learners' demand and encourage teachers to explore quality resource by means of set-up projects based on university resource, in order to provide better user experience and service for society through opening and sharing.

\section{ACKNOWLEDGMENT}

This research was financially supported by National Education Science "12th Five-Year plan" key project of Ministry of Education "The construction of the college and enterprise sharing service platform for financial knowledge resources based on cloud computing", the project number is DCA130225.

\section{REFERENCES}

[1] Yang, X.H., \& Jia, W. Research on Digital Learning Resource Construction under Modern Learning Principles [J]. Chinese AudioVisual education, 2013, (3): 84-88, 95. (in Chinese)

[2] Ten-year plan on information education (2011-2010). (in Chinese)

[3] Zhu, Z.T., Xu, Z. \& Liu, M.Z.. New Development and Motivation Analysis of Digital Education Resource Construction [J]. Chinese Audio-Visual education, 2012, (2): 1-5. (in Chinese)

[4] Li Y.. "Internet+" China is Entering Internet Profit Era [M]. China's Ministry of Industry and Information Technology Publishing Group, 2016. 3: 348. (in Chinese)

[5] Jiang, L.B., Wan, L.Y. \& Yu, Y.. User Experience Model Research on Digital Learning Resource [J]. Modern Education Technology, 2017, 27 (03): 85-92. (in Chinese)

[6] Baidu Encyclopedia. Spirit of the Internet [EB/OL]. https://baike.baidu.com/item/\%E4\%BA\%92\%E8\%81\%94\%E7\%BD\%9 $1 \% \mathrm{E} 7 \% \mathrm{~B} 2 \% \mathrm{BE} \% \mathrm{E} \% \mathrm{~A} 5 \% 9 \mathrm{E} / 9867749$ ?fr=aladdin. 2017.9.(in Chinese)

[7] Atkins,D. E., Brown, J. S., Hammond, A. L.. A Review of the Open Educational Resources (OER)Movement [DB/OL].

[8] Toffler, A. the Third Wave [M] (M.J. Huang Trans). Beijing CITIC Press, 2006. (in Chinese)

[9] Lu F. \& Li, K.D.. Web2.0 Based PLE Structure Model Construction Research (J). Educational Technology Research, 2016, 37(10): 51-56. (in Chinese)

[10] Yang, X.M. \& Zhao, X.S.. Recognition and Trend of Learning Resource in "Internet+" Era [J]. Educational Technology Research,2016, 37 (10): 88-96. (in Chinese)

[11] Yang, X.M. \& Yu, S.Q... Ubiquitous Learning Environment Plan in Ecological Aspect [J]. Educational Research, 2013, (3): 98-105. (in Chinese) 